\title{
ANALISIS FAKTOR-FAKTOR PEMBANGUNAN DESA DAN STRATEGI MENUJU DESA MANDIRI \\ (Studi Kasus di Desa Batang Sangir \\ Kecamatan Kayu Aro Kabupaten \\ Kerinci)
}

\section{NANIK MANDASARI}

\author{
Sekolah Tinggi Ilmu Administrasi Nusantara Sakti (STIA_NUSA) \\ Sungai Penuh-Kerinci \\ mandasarinanik@gmail.com
}

\begin{abstract}
ABSTRAK
Analysis of Village Development Factors and Strategies Towards Independent Villages (Case Study in Batang Sangir Village, Kayu Aro District, Kerinci Regency). This study aims to determine the Factors of Development of Batang Sangir Village and Strategies Towards Independent Villages. This type of research is descriptive with a qualitative approach. The research location is in Batang Sangir Village, Kayu Aro District, Kerinci Regency with a purposive sampling technique. This study uses data collection techniques: interviews, observation, and documentation. The results of this study are, the development factors in Batang Sangir Village include: (1) Natural Resources. (2) Human Resources. (3) Economy. (4) Public Services. (5) Community Participation. Batang Sangir Village applies a strategy towards independent villages from within, namely: optimizing the initiative or desire of the community to progress, optimizing the capacity / ability of the community, optimizing the capacity of the village head in organizing. Facilitate bureaucracy and facilitate constructive activities. Strengthening village officials' human resources through training and coaching and involving the community in development. Conduct village meetings which include community leaders, religious leaders. Determine productive businesses in Batang Sangir Village.
\end{abstract}

Keywords: Village, Village Build Index, Independent Village

\section{ABSTRAK}

Penelitian ini bertujuan untuk mengetahui Faktor-Faktor Pembangunan Desa Batang Sangir Dan Strategi Menuju Desa Mandiri. Tipe penelitian ini adalah deskriptif dengan pendekatan kualitatif. Lokasi penelitian berada di Desa Batang Sangir Kecamatan Kayu Aro Kabupaten Kerinci dengan teknik purposive sampling. Penelitian ini menggunakan teknik pengumpulan data: wawancara, observasi, dan dokumentasi. Hasil dari penelitian ini adalah, faktor-faktor pembangunan di Desa Batang Sangir antara lain: (1) Sumber Daya Alam. (2) Sumber Daya Manusia. (3) Ekonomi. (4) Pelayanan Publik. (5) Partisipasi Masyarakat. Desa Batang Sangir menerapkan strategi menuju desa mandiri dari 
dalam yaitu: mengoptimalkan prakarsa atau keinginan masyarakat untuk maju, mengoptimalkan kapasitas/kemampuan masyarakat, mengoptimalkan kapasitas kepala desa dalam mengorganisir. Mempermudah birokrasi dan memfasilitasi kegiatan-kegiatan yang sifatnya membangun. Memperkuat SDM perangkat desa melalui pelatihan dan pembinaan serta mengikutsertakan masyarakat dalam pembangunan. Melakukan musyawarah desa yang diikutsertakan di dalamnya tokoh masyarakat, tokoh agama. Menentukan usaha-usaha yang produktif di Desa Batang Sangir.

\section{Kata Kunci : Desa, Indeks Desa Membangun, Desa Mandiri}

\section{PENDAHULUAN}

\section{Latar Belakang Masalah}

Salah satu poin yang paling penting dalam pembahasan Peraturan Menteri Desa No 2 Tahun 2016 adalah terkait indeks desa membangun. Namun dalam penerapannya ada saja hal yang menjadi hambatan desa dalam menuju desa mandiri seperti sumber daya alam, letak geografis, dsb. Selain itu tingkat kesiapan tata kelola yang masih rendah dan kurangnya sumber daya manusia (SDM) yang ada di desa, juga dapat menghambat tujuan desa menjadi desa mandiri.

Desa Batang Sangir Kecamatan Kayu Aro Kabupaten Kerinci, merupakan salah satu desa yang statusnya sudah Desa berkembang, atau bisa disebut sebagai desa madya adalah desa potensial menjadi desa maju, yang memiliki potensi sumber daya sosial, ekonomi, dan ekologi tetapi belum mengelolanya secara optimal untuk peningkatan kesejahteraan masyarakat desa, kualitas hidup manusia dan menanggulangi kemiskinan.

Desa Batang Sangir sebenarnya mempunyai banyak potensi yang menjanjikan untuk menjadi desa mandiri, salah satunya di Desa Batang Sangir terdapat BUMDES yang mana BUMDES ini memproduksi kopi bubuk dan juga Kompos, sebagai mana yang kita tahu saat ini bahwa kopi menjadi minuman yang diminati mayoritas masyarakat dan juga harga kopi juga mahal hal ini menjadi pendapatan bagi Desa Batang Sangir ini. Dalam bidang Peternakan, Desa Batang Sangir merupakan produksi Sapi dan Kambing, dan juga banyak kolam-kolam ikan yang dimiliki oleh masyarakat. Selain peternakan dan perikanan, Pertarion di Batang Sangir juga memiliki potensi untuk menjadi desa mandiri yaitu ban vi ra lahan yang dimiliki oleh masyarakat. Dari sektor home industri, terdapat juga potensi yang berasal dari usaha kecil menengah seperti keripik wortel, talas, dan singkong, juga ada usaha toko-toko dan Gudang-gudang kentang yang cukup dikenal. Di Desa Batang Sangir juga terdapat pasar yang cukup ternama di Daerah kayu Aro yaitu pasar Kersik Tuo.

Desa Batang Sangir sekilas sudah cukup maju dilihat dari keadaan rumah rumah warga, dan keadaan desa secara umum. Dengan segala potensi yang dimiliki serta keadaan desa yang terlihat sudah cukup baik, Sumber Daya Manusia nya pun tergolong baik dimana terlihat bahwa tinggi nya kesadaran masyarakat akan pentingnya suatu pendidikan dilihat dari tingkat pendidikan yang diselesaikan oleh masyarakat dan sudah banyak yang melanjutkan ke perguruan tinggi, Ekonomi Masyarakat Desa Batang Sangir Di kategorikan ekonomi kelas menengah ke atas dilihat dari bangunan rumah-rumah warga yang dalam kategori layak dan juga 
mayoritas masyarakatnya bekerja sebagai petani, pelayanan publik yang sangat baik dilihat dari aktifitas kantor desa yang buka sampai hari jum'at dan kegiatan administrasi yang lancar dan jelas, sarana dan prasarana yang tersedia bagi masyarakat. Partisipasi masyarakat yang aktif dalam kegiatan pembangunan desa dan masyarakat yang ikut menjaga dan melestarikan nya. Dari faktor-faktor pembangunan tersebut akhirnya Desa Batang Sangir termasuk desa berkembang. Tak luput dengan prestasi desa berkembang pemerintah Desa Batang Sangir terus melakukan upaya untuk meningkatkan status desa menjadi desa mandiri.

Berdasarkan latar belakang masalah tersebut di atas, maka penulis menganggap perlu diadakannya penelitian mengenai "ANALISIS FAKTORFAKTOR PEMBANGUNAN DESA DAN STRATEGI MENUJU DESA MANDIRI (Study Kasus Di Desa Batang Sangir Kecamatan Kayu Aro Kabupaten Kerinci)". Pemilihan Desa Batang Sangir sebagai tempat penelitian disebabkan keadaan Desa Batang Sangir yang sudah berkembang.

\section{Rumusan Masalah}

Berdasarkan latar belakang masalah yang telah dijabarkan di atas maka rumusan masalah yang ada adalah :

1. Apa saja faktor-faktor dalam pembangunan desa?

2. Bagaimanakah strategi Desa Batang Sangir Menuju desa mandiri?

\section{METODE PENELITIAN}

Penelitian tentang Analisis Faktor-Faktor Pembangunan Desa Dan Strategi Menuju Desa Mandiri peneliti menggunakan pendekatan penelitian deskriptif dengan pendekatan kualitatif. Pendekatan kualitatif adalah prosedur penelitian yang menghasilkan data deskriptif berupa kata-kata tertulis atau lisan dari orang-orang dan prilaku yang dapat diamati (Moleong, 2002:3).

Metode penelitian kualitatif membuka ruang yang cukup bagi dialog ilmu dalam konteks yang berbeda, terutama apabila ia dipahami secara mendalam dan "tepat". Penelitian kualitatif dapat mengeksplorasi sikap, prilaku, dan pengalaman responden melalui metode interview dan fokus group. Pendekatan ini diharapkan mampu menjaring realita dilapangan dengan mengumpulkan data secara langsung dilapangan melalui wawancara, dokumentasi dan observasi.

Dalam penelitian ini peneliti menggunakan informan kunci (key informan) dan informan biasa. Informan kunci merupakan informan yang mengetahui secara mendalam permasalahan yang sedang diteliti, sedangkan informan biasa merupakan informan yang ditentukan dengan dasar pertimbangan mengetahui dan berhubungan dengan permasalahan. Dalam hal ini penulis menggunakan metode purposive sampling. Yaitu pengambilan sampel yang di sesuaikan dengan tujuan dan syarat tertentu yang ditetapkan berdasarkan tujuan dan masalah penelitian.(Nawawi, 1987:157). Dalam penelitian ini peneliti telah menemukan 8 orang informan.

\section{Teknik Dan Alat Pengumpulan Data}
a. Observasi
b. Wawancara
c. Dokumentasi 


\author{
Analisis Data \\ Di dalam melakukan analisis data penelitian mengacu kepada beberapa \\ tahapan yaitu: \\ 1. Pengumpulan informasi melalui wawancara. \\ 2. Reduksi data (data reduction) \\ 3. Penyajian data(data display) \\ 4. Kesimpulan atau verifikasi (conslusion)
}

\title{
III. HASIL DAN PEMBAHASAN
}

\section{Analisis Faktor-faktor Pembangunan Desa}

Dari Beberapa faktor yang mempengaruhi terhadap pembangunan Desa sebagaimana yang dikemukakan Mareine Warouw (2015 : 49) yaitu:

\section{Sumber Daya Alam}

Sumber Daya Alam yaitu terdiri dari luas lahan yang dimiliki oleh masyarakat, hasil dan jenis-jenis komuditi tanaman pertanian dan komuniti peternakan. Berdasarkan penelitian yang penulis lakukan di Desa Batang Sangir di dapatkan informasi bahwa sebelum melaksanakan pembangunan di Desa Batang Sangir telah mempunyai perencanaan/persiapan. Sebagaimana yang telah dijelaskan oleh Bapak Jamio Selaku Kepala Desa Batang Sangir dalam Penjelasannya:

"Berdasarkan pengamatan Kami bahwa rata-rata penduduk yang berada di Desa Batang Sangir memiliki lahan dan kawasan pertanian yang luas, bahkan lahan yang di miliki oleh penduduk merupakan lahan milik sendiri yang merupakan lahan dari orang tua dan nenek moyang mereka dan bahkan ada sebagian penduduk yang membeli langsung dari lahan pertanian tersebut untuk menambah penghasilan 455mereka, dan dari pengamatan Kepala Desa bahwa rata-rata penduduk dapat mengembangkan usaha di bidang peteranakan karena lokasi pertanian yang luas dan subur untuk usaha peternakan, seperti contohnya adalah peternakan sapi, Kambing dan Ayam, dan banyak juga masyarakat yang beternak ikan, untuk menambah penghasilan masyarakat desa ".

Dari penelitian ini Sebagaimana juga yang telah dijelaskan oleh Bapak Nani Sugianto, SE, Selaku Sekretaris Desa dalam Penjelasannya:

"Dalam rangka pembanguna desa di Batang Sangir masyarakat

telah banyak melakukan usaha-usaha pertanian seperti menanam

kentang, jagung, kacang dan lain sebagainya di karenakan sumber

daya alam yang memadai untuk mengembangkan hasil pertanian

di Desa Batang Sangir".

Selanjutnya Meswanto selaku masyarakat biasa didesa batang sangir mengatakan :

"Kita di batang sangir ini rata-rata penduduk nya adalah petani, ada yang bekerja dilahan pribadi dan ada yang bekerja di lahan orang lain dan sebagainya ada juga yang bekerja sebagai karyawan di perkebunan teh, lahan yang dimiliki oleh masyarakat disini tidak semua terletak di desa batang sangir, contohnya saya sendiri mempunyai lahan yang terletak di desa bengkolan dua yaitu desa tetangga".

Dari hasil wawancara dengan informan diatas, berdasarkan teori yang dikemukakan oleh Mareine Warouw indikator Sumber Daya Alam yang terdiri dari 
luas lahan yang dimiliki oleh masyarakat dan jenis-jenis komuditi pertanian dan peternakan dapat disimpulkan bahwa masyarakat desa batang sangir memiliki lahan pertanian, lahan tersebut adalah merupakan lahan milik sendiri yang merupakan lahan dari orang tua yang di turunkan secara turun temurun dan ada juga sebagian dari masyarakat yang membelinya, kemudian masyarakat juga mempunyai berbagai jenis komuditi peternakan yang di antaranya peternakan sapi, kambing dan ayam, dan ada juga ikan. Hal ini peneliti mengambil kesimpulan bahwa Sumber Daya Alam di desa batang sangir sudah sama dengan teori dari indikator sumber daya alam menurut Mareine Warouw.

\section{Sumber Daya Manusia}

Yaitu terdiri dari tingkat pendidikan yang di selesaikan dan kemampuan keterampilan yang dimiliki masyarakat Dalam hal ini Sebagaimana yang telah dijelaskan oleh Bapak Jamio, Selaku Kepala Desa dalam Penjelasannya:

"Pendidikan masyarakat Di Desa Batang Sangir ini sudah sangat baik, kami melihat masyarakat sudah merasa bahwa pendidikan ini sangat penting, contohnya banyaknya anak-anak muda yang melanjutkan ke perguruan tinggi bahkan ada yang ke luar daerah, tingkat pendidikan di desa kami ini pemerintah menyediakan sarana dan prasarana mulai dari PAUD, TK, SD, dan SMP. Dengan berkembangnya kemajuan teknologi dan banyaknya alatalat pertanian dan obat-obat pertanian untuk meningkatkan hasil pertanian, sebagian masyarakat telah memiliki keterampilan dan pengetahuan dalam bidang pertanian dan peternakan di Desa Batang Sangir contohnya keterampilan dalam beternak sapi dan ayam".

Sebagimana Dalam hal ini juga telah dijelaskan oleh Bapak Nani Sugianto,

SE, Selaku Sekretaris Desa dalam Penjelasannya:

"Tingkat pendidikan masyarakat didesa Batang Sangir ini bermacam mulai dari Sekolah Dasar samapai ketingkat perguruan tinggi, Namun rata-rata pendidikan masyarakat adalah tamatan SMA, Bahwa selain kemampuan masyarakat yang di dapat dari perkembangan ilmu pengetahuan, pemerintahan desa juga telah melaksankan bimbingan dan training untuk keterampilan-keterampilan yang sesuai dengan bidang kemampuan masyarakat dalam menambah pengetahuan mereka".

Selanjutnya Jawahir selaku tokoh Adat :

"Tingkat pendidikan masyarakat Desa Batang Sangir sejauh ini kami melihat rata-rata kebanyakan masyarakat tamatan SLTA, Namun ada juga yang melanjutkan ke perguruan tinggi, dalam kegiatan sehari-hari masyarakat cukup terampil atau telah terlatih dalam kegiatan bertani dan beternak contohnya, hal ini mungkin karena sudah kebiasaan masyarakat dalam melakukannya".

Dari hasil wawancara dengan informan berdasarkan pendapat Mareine Warouw berdasarkan indikator Sumber daya manusia yakni tingkat pendidikan yang diselesaikan oleh masyarakat dan kemampuan dan keterampilan yang dimiliki oleh masyarakat. dapat dilihat bahwa Sumber Daya Manusia yang di lihat dari indikator tingkat pendidikan masyarakat bahwa tingkat pendidikan di desa batang sangir ini sangat baik hal ini dikarenakan Masyarakat sudah memahami akan pentingnya pendidikan, selanjutnya dilihat dari indikator kemampuan keterampilan yang dimiliki oleh masyarakat dalam bidang pertanian dan peternakan masyarakat sudah cukup terampil, keterampilan tersebut memang keahlian dari masyarakat itu 
sendiri dan juga ada nya bimbingan dari dinas terkait. Jadi kesimpulannya untuk Sumber Daya Manusia sesuai dengan teori dari indikator Sumber Daya Manusia sudah tergolong Cukup baik.

\section{Ekonomi}

Yaitu terdiri dari pajak-pajak dan pendapatan masyarakat yang dapat menambah penghasilan Pemerintah. Dalam hal ini Sebagaimana yang telah dijelaskan oleh Bapak Jamio, Selaku Kepala Desa dalam Penjelasannya:

"Bahwa setiap masyarakat yang berdomisili di Desa Batang Sangir akan di kenakan Pajak rumah yaitu dalam bentuk pajak PBB yang di pungut oleh Pemerintahan Desa setiap tahun. Serta bagi masyarakat yang memliki usaha tersendiri yang telah berkembang akan dikenakan pajak daerah dengan mengurus surat izin dari pemerintahan yang berwenang dan dari kelompok tani pemerintah desa juga menerima bagi hasil. Dan BUMDES juga salah satu bagian dari perekonomian Desa.".

Kemudian di jelaskan oleh Bapak Nani Sugianto S.E, Selaku sekretaris Desa beliau mengatakan :

"Untuk setiap masyarakat yang bertempat tinggal di Desa Batang Sangir akan di kenakan Pajak Bumi dan Bangunan yaitu dalam bentuk pajak PBB yang di pungut oleh Pemerintahan Desa setiap tahun. Disamping itu di desa batang sangir yang terdapat pasar yang dalam hal ini juga merupakan pengasilan desa yang berupa pajak. Serta bagi masyarakat yang memliki tempat usaha menengah keatas akan dikenakan pajak daerah dengan mengurus surat izin dari pemerintahan yang berwenang".

Selanjutnya Aminah S.kom selaku KASI pelayanan di desa batang sangir, terkait pertanyaan peneliti, menjelaskan :

"Salah satu pendapatan desa yakni berupa pajak, pajak dalam hal ini di minta kepada masyarakat yang di bayar setiap setahun sekali berupa PBB yakni pajak bumi dan bangunan. pasar yang terdapat di desa batang sangir juga berperan dalam meningkatkan perekonomian desa. Serta bagi masyarakat yang memliki tempat usaha ekon omimenengah keatas akan dikenakan pajak daerah dengan mengurus surat izin dari pemerintahan yang berwenang".

Selanjutnya Jawahir selaku Tokoh Adat :

"Perekonomian di Batang Sangir ini berdasarkan pendapatan masyarakat mayoritas masyarakat bekerja sebagai petani, dan ada juga sebagai pengusaha atau membuka usaha sendiri dan ada juga yang berjualan di Pasar Desa Batang Sangir"

Selanjutnya Meswanto selaku masyarakat didesa batang sangir mengatakan :

"Kami selaku masyarakat tentunya mematuhi peraturan yang sudah berlaku dari dulu yang mana setiap tahunnya kami di pungut yang namanya pajak bumi dan bangunan yang hasilnya juga berguna bagi desa batang sangir sendiri.selain itu kami juga melihat bahwa setiap orang yang berjualan di pasar desa batang sangir akan di pungut pajak juga ".

Dari hasil wawancara dengan informan di atas terkait dengan teori yang dikemukakan oleh Mareine Warouw yang berkaitan dengan ekonomi dengan indikator Ekonomi yakni dari pajak-pajak dan tingkat pendapatan masyarakat bahwa di desa batag sangir memiliki penghasilan dari Pajak Bumi dan Bangunan atau di sebut dengan PBB, kemudian pajak tempat usaha bagi masyarakat yang 
mempunyai indurti atau usaha kelas menengah keatas dan juga pajak tempat-tempat usaha yang berada di pasar desa batang sangir. Tingkat pendapatan masyarakat desa batang sangir rata-rata ekonomi kelas menengah keatas dan kemudian pendapatan Desa juga Di peroleh dari BUMDES Desa Batang Sangir. Hal ini sudah sama dengan teori indikator Ekonomi yang mana di Desa Batang Sangir terdapak hasil Dari pemungutan Pajak dan pendapatan masyarakat yang ekonomi klas menengah ke atas.

\section{Pelayanan Publik}

Yaitu terdiri dari pelayanan dalam realisasi pembangunan, pelayanan kinerja aparat, ketepatan waktu pelayanan administrasi, pelayanan ketersediaan sarana dan prasarana. . Dalam hal ini Sebagaimana yang telah dijelaskan oleh Bapak Bapak Jamio Selaku Kepala Desa Batang Sangir dalam Penjelasannya:

"Bahwa pemerintahan desa selalu secara maksimal akan melayani, mengayomi masyarakat dengan sebaik-baiknya baik dalam bidang pengurusan surat menyurat, memecahkan permasalah yang ada di dalam Desa bahka pemerintah Desa selalu memberikan kemudahan-kemudahan dalam hal pelayanan-pelayanan kebutuhan masyakarat sesuai dengan peratuan dan undang-undang yang berlaku dalam daearah, dan juga kami selaku pemerintahan desa menyediakan sarana dan prasarana yang di butuhkan oleh masyarakat sesuai dengan minatnya masing-masing contohnya terdapat gedung badminton dan futsal, rumah baca, lapangan sepak bola dan lainsebagainya".

Selanjutnya di jelaskan oleh Bapak Nani Sugianto selaku Sekretaris Desa beliau mengatakan :

"Kalo kita berbicara tentang pelayanan publik, mungkin disetiap pemerintahan desa akan berusaha memberikan pelayanan yang terbaik untuk masyarakatnya, hal ini pun juga demikian dengan pemerintah desa batang sangir, kami berupaya untuk memberikan yang terbaik untuk masyarakat kami baik itu dalam segi formal maupun informal. Dan juga setiap kebutuhan masyarakat terkait dengan sarana dan prasarana yang berhubungan tujuan pembangunan desa kami akan selalu memfasilitasi kebutuhan masyarakat kami tersebut".

Selanjutnya Jawahir Selaku Tokoh Adat :

"Kami melihat pemerintah desa batang sangir ini khususnya di kecamatan kayu aro termasuk yang pemerintah desa nya yang paling aktif kami selaku bagian dari masyarakat sangat terbantu dalam setiap urusan kami yang mana setiap kami ingin mengurus surat menyurat kami bisa langsung datang ke kantor desa, dan di kantor selalu ada petugasnya setiap hari senin sampai dengan hari jum'at, apalagi hari senin kami melihat pemerintah nya datang semua karena menurut informasi dari pak kades bahwa setiap hari senin diwajibkan bagi aparatur pemerintahan desa untuk hadir. Dan dalam kegiatan kepemudaan kami juga merasa terbantu dengan adanya sarana dan prasarana yang di berikan oleh desa".

Selanjutnya Meswanto selaku masyarakat biasa didesa batang sangir mengatakan : "di Desa batang sangir ini kami selaku masyarakat sudah sangat puas dengan pelayanan, karena kami melihat pemerintah desa batang sangir ini cukup aktif dalam penyelenggaraan kegiatan,struktur-struktur nyapun berfungsi dan bekerja pada tugasnya masing-masing. Dan kami melihat 
kantor kepala desa nya pun tidak pernah kosong terkecuali hari libur, jadi kami selaku masyarakat dalam setiap urusan surat menyurat, membuat kartu keluarga, KTP kami merasa sangat terbantu tanpa ada hambatan karena kami bisa menemui petugasnya langsung ke kantor desa".

Dari Hasil wawancara dengan informan di atas dapat dilihat bahwa Pelayanan Publik di Desa Batang Sangir sudah tergolong baik sesuai dengan teori indikator pelayanan publik, bahwa pemerintah telah memberikan pelayanan yang baik kepada masyarakat dalam realisasi pembangunan, ketepatan waktu dalam administrasi bahwa masyarakat tidak pernah merasa terhambat dengan pelayanan administrasi, dan pemerintah juga menyediakan sarana dan prasarana sesuai dengan kebutuhan dan minat masyrakat.

\section{Partisipasi Masyarakat}

Yaitu meliputi keterlibatan masyarakat dalam pembangunan desa lewat kehadiran rapat, ketersediaan memberi bantuan tenaga, uang, bahan dan pemeliharaan dan menjaga pembangunan.

Dalam hal ini Sebagaimana yang telah dijelaskan oleh Bapak Bapak Jamio Selaku Kepala Desa Batang Sangir dalam Penjelasannya:

"Setiap permasalahan dan rencana pembangunan desa, pemerintah desa selalu melibatkan masyarakat untuk merencanakan pembangunan desa yang harus di prioritaskan, dalam hal ini biasa nya sebelum melakukan pengembangan dengan selalu dilakukan rapat desa untuk menentukan kebijakan-kebijakan dalam hal pembangunan desa yang dapat memberi manfaat bagi masyarakat. Kami juga sangat salut kepada masyarakat yang mana masyarakat selalu ikut andil dalam proses pembangunan di desa batang sangir ini, baik menyumbangkan tenaga dalam bentuk gotong royong,menyumbangkan pikiran dalam setiap musyawarah dengan pemerintah desa, dan masyarakat tak luput memberikan bantuan berupa uang untuk kepentingan masyarakat bersama. Kemudian masyarakat juga sangat membantu dalam memelihara dan menjaga sarana dan prasarana yang ada di desa batang sangir ini".

Sebagaiman juga yang telah di sampaikan oleh Bapak Nani Sugianto S.E selaku Sekretaris Desa :

"Bahwa pada saat ini masyarakat telah memiliki kemampuan untuk memberikan sumbangsih dalam bentuk pemikiran, tenaga bahkan moril demi ketercapaian suatu desa yang baik dan mandiri salah satunya adalah sikap gotong royong dan kepedulian masyarakat masih sangat baik di Desa Batang Sangir".

Selanjutnya Meswanto selaku masyarakat biasa didesa batang sangir mengatakan :

"Setiap kegiatan atau acara yang diselenggarakan oleh pemerintah desa kami tidak segan-segan untuk ikut andil dalam kegiatan atau acara tersebut selama kegiatan atau acara tersebut sifat nya positif dan berguna bagi masyarakat banyak".

Selanjutnya Mugiono Selaku Tokoh Pemuda mengatakan :

"Melihat pemerintahan desa yang aktif menyelenggarakan kegiatan tentunya kami dari masyarakat akan mendukung kegiatan tersebut selama kegiatan tersebut positif dan tidak merugikan.tapi untuk sejauh ini kami melihat kegiatan-kegiatan yang bermanfaat cotohnya saja misalnya di bulan 
suci ramadan sudah menjadi rutinitas didesa kami mengadakan pawai yang mana di ikuti oleh anak-anak dari pengajian dan masyarakat desa setempat dan kami selaku pemudapun selalu di ajak berpartisipasi dalam kegiatan tersebut,karena mungkin itu dari kami yang mampu kami berikan dalam kesuksesan kegiatan didesa batang sangir".

Dari hasil wawancara dengan informan terkait indikator partisipasi masyarakat meliputi keterlibatan masyarakat dalam pembangunan desa lewat kehadiran rapat, ketersediaan memberi bantuan tenaga, uang, bahan dan pemeliharaan dan menjaga pembangunan sudah berjalan dengan baik dilihat dari keikutsertaan masyarakat setiap rapat dan memberi bantuan tenaga dalam kegiatan pembangunan dalam bentuk gotong royong, dan masyarakat ikut menjaga dan melestarikan pembangunan desa batang sangir.

Berdasarkan hasil wawancara dari berbagai sumber, dapat disimpulkan bahwa, sebelum melakukan Pelaksanaan pembangunan Desa di Desa Batang Sangir Kecamatan Kayu Aro perangkat desa selalu melakukan Koordinasi terhadap masyarakat dan selalu menjaga komunikasi dengan baik, dan keterlibatan masyarakat akan menentukan baik tidak nya suatu desa, Sumber daya alam dan sumberdaya manusia merupakan suatu faktor yang mendukung pembangunan Desa, dari hasil penelitian yang penulis lakukan dapat di simpulkan bahwa Sumber Daya Alam, Sumber daya Manusia, Ekonomi, Pelayanan Publik serta keteralibatan Masyarakat sudah tergolong baik, Namun dari segi tingkat pendidikan masih tergolong rendah hal ini di sebabkan oleh dorongan faktor lingkungan masyarakat yang pada umumnya masyarakat di Desa Batang Sangir pekerjaannya adalah Petani.

\section{KESIMPULAN}

Berdasarkan hasil dan pembahasan, maka peneliti dapat menarik simpulan sebagai berikut.

1. Faktor-faktor Pembangunan Desa Batang Sangir antaralain. Sumberdaya Alam yang ada,dilihat dari luas lahan yang dimiliki oleh masyarakat dan juga jenis komuditi pertanian dan peternakan yang dimiliki oleh masyarakat. Sumber daya Manusia yang dilihat dari indikator tingkat pendidikan masyarakat yang sudah menyadari akan pentingnya suatu pendidikan dan keterampilan dan kemampuan yang dimiliki oleh masyarakat,. Ekonomi Mayarakat yang tergolong ekonomi kelas menengah keatas dan telah maju dengan banyaknya usaha-usaha pertanian, peternakan dalam Desa Batang Sangir. serta keterlibatan masyarakat akan menentukan baik tidak nya suatu kemajuan desa, Pelayanan publik yang cukup baik dimana masyarakat sangat merasa puas dengan pelayanan administrasi di Desa dan juga tersedianya sarana Dan prasarana untuk masyarakat sesuai dengan hobi dan minat masing-masing. Partisipasi masyarakat yang cukup tinggi di lihat dari keikutsertaan masyarakat dalam mengikuti musyawarah dan menjaga pembangunan . komunikasi dan pendidikan merupakan suatu faktor yang mendukung pembangunan Desa, dari hasil penelitian yang penulis lakukan dapat di simpulkan bahwa Keterlibatan Masyarakat, Kepemimpinan dan Komunikasi dengan masyarakat sudah tergolong baik.

2. Desa Batang Sangir menerapkan strategi menuju desa mandiri dari dalam, yaitu: Desa Batang Sangir mempermudah birokrasi dan memfasilitasi 
kegiatan-kegiatan yang sifatnya membangun. Desa Batang Sangir memperkuat Sumber Daya Manusia perangkat desa melalui pelatihan dan pembinaan serta mengikutsertakan masyarakat dalam pembangunan. Desa Batang Sangir melakukan musyawarah desa yang diikutsertakan di dalamnya tokoh masyarakat, tokoh agama. Desa Batang Sangir menentukan usaha-usaha yang produktif di Desa Batang Sangir. Potensi yang ada di Desa Batang Sangir untuk menjadi desa mandiri antara lain, dari sumber daya alam seperti hasil perkebunan dan pertanian, agrowisata, peternakan, serta home industry. Hambatan Batang Sangir dalam menuju desa mandiri, yang pertama adalah hambatan dari masyarakat itu sendiri. Hambatan yang kedua adalah masalah finansial. Hambatan yang ketiga adalah penggunaan teknologi yang masih rendah.

\section{Saran}

Adapun saran-saran yang dapat diberikan sehubungan dengan hasil penelitian ini adalah sebagai berikut :

1. Untuk menjadikan Desa Batang Sangir menjadi desa mandiri, Desa Batang Sangir harus mengoptimalkan prakarsa atau keinginan untuk maju. Mengoptimalkan kemampuan masyarakat. Serta mengoptimalkan kemampuan kepala desa untuk mengorganisir masyarakatnya.

2. Untuk mengatasi hambatan seperti masyarakat yang belum tumbuh kesadarannya, belum ada rasa memiliki desa, rasa tanggungjawab, rasa kebersamaan yang bersama-sama ingin membangun dan mengembangkan desa. Sebaiknya pemerintah melakukan sosialisasi serta mengajak masyarakat ikut serta dalam setiap kegiatan desa seperti musyawarah desa agar timbulnya kesadaran masyarakat untuk ikut serta dalam pembangunan desa. Masyarakat juga harus mempunyai kesadaran untuk ikut serta dalam setiap kegiatan pembangunan desa karena merekalah yang akan merasakan dampak baik ataupun buruk dari kegiatan pembangunan desa.

3. Untuk masalah finansial dalam pembangunan seperti sarana dan prasarana, pemerintah desa dapat mengatasinya dengan melakukan skala prioritas mengenai apa saja program yang lebih dulu dijalankan dan memanfaatkan swadaya masyarakat supaya efisien. Untuk penggunaan teknologi yang kurang sebaiknya desa mulai melakukan pelatihan seperti kursus komputer untuk aparatur desa agar dapat mengoperasikan teknologi komputer dengan baik.

\section{UCAPAN TERIMA KASIH}

Dalam kesempatan ini izin kan penulis mengucapkan terimakasih kepada kepada unsur pimpinan STIA NUSA Sungai Penuh yang telah mendukung penulis dalam pelaksanaan penelitian ini baik dukungan secara moril maupun materil. Ucapan terimakasih juga kami sampaikan kepada Ketua Lembaga Penelitian dan Pengabdian Masyarakat (LPPM) STIANUSA Sungai Penuh beserta seluruh Tim Editor yang telah bersedia untuk menerbitkan naskah artikel yang dimuat pada adisi ini.

\section{A. Buku}

\section{DAFTAR PUSTAKA}

Adi Isbandi Rukminto, (2013), Intervensi Komunitas \& Pengembangan Masyarakat Sebagai Upaya Pemberdayaan Masyarakat, Jakarta, Rajawali Pers. 
Bustanul Arifin, (2004), Analisis Ekonomi Pertanian Indonesia, Jakarta, Penerbit Buku Kompas.

Gunawan Soemodiningrat, (2009), Membangun Perekonomian Rakyat, Yogyakarta, IDEA dan Pustaka Pelajar.

Jamasy Owin, (2004), Keadilan, Pemberdayaan dan Penanggulangan Kemiskinan, Bandung, Blantika Mizan.

Lexy J. Moleong, (2006), Metodologi Penelitian Kualitatif, Bandung, PT. Remaja Rosdakarya.

Mardikanto dan Soebianto, (2012), Pemberdayaan Masyarakat dalam Perspektif Kebijakan Publik, Bandung, Alfabeta.

Miles, B. Matthew., Huberman, A. Michael, 2006, Qualitative Data Analysis, a Sourcebook of New Methods, California, SAGE Publication Inc.

Sugiyono, (2012), Memahami Penelitian Kualitatif, Bandung, Alfabeta.

\section{B. Jurnal}

Republik Indonesia. (2014). Undang-undang Nomor 6 Tentang Desa.

Republik Indonesia. (2015). Peraturan Menteri Desa, Pembangunan Daerah Tertinggal, dan Transmigrasi Nomor 5 Tentang Penetapan Prioritas Penggunaan Dana Desa.

Irawan N. (2017). Tata Kelola Pemerintahan Desa Era UU Desa. Jakarta: Yayasan Pustaka Obor Indonesia.

Sujono. (2017). Mengembangkan Potensi Masyarakat di Desa/Kelurahan 77 Catatan dalam 4 Model Pengembangan (Pemanfaatan Sampah, Optimalisasi Industri Rumahan, Mengembangkan Desa Wisata dan Menciptakan Wirausaha Desa). Yogyakarta: Deepublish. 